\title{
The protective effect of Amomum xanthoides extract against alloxan-induced diabetes through the suppression of NFKB activation
}

\author{
Byung-Hyun Park ${ }^{1,2}$ and Jin-Woo Park ${ }^{1}$ \\ ${ }^{1}$ Department of Biochemistry and Institute for Medical Sciences, \\ Chonbuk National University Medical School, Chonju 561-756, \\ Korea \\ ${ }^{2}$ Corresponding author: Tel, +82-63-270-3139; \\ Fax, +82-63-274-9833; E-mail, bhpark@ moak.chonbuk.ac.kr
}

Accepted 24 May, 2001

Abbreviations: DTT, dithiothreitol; EDTA, ethylenediaminetetraacetic acid; EMSA, electrophoretic mobility shift assay; iv, intravenous; ip, intraperitoneum; ROS, reactive oxygen species

\begin{abstract}
This study was undertaken to investigate the preventive mechanism of Amomum xanthoides extract against the development of alloxan-induced diabetics of mice. Pretreatment of mice with A. xanthoides extract via intraperitoneum prevented alloxan-induced hyperglycemia and hypoinsulinemia in a dose dependent manner. Histological examination of pancreatic tissue from $A$. xanthoides extract treated mice showed that the islet cells remain unaffected by alloxan treatment. NFKB activation in the pancreas $30 \mathrm{~min}$ after alloxan injection $(60 \mathrm{mg} / \mathrm{kg}$, iv), as assessed by an electrophoretic mobility shift assay, was not detected in the mice pretreated with $A$. xanthoides extract. These results suggest that NFKB activation may be one of the critical determinant in the progression of the disease. Considering the preventive effect of $\boldsymbol{A}$. xanthoides extract from alloxaninduced diabetics development, these results may provide the possible therapeutic value of $A$. xanthoides extract for the prevention of diabetes mellitus progression.
\end{abstract}

Keywords: Amomum xanthoides, alloxan, NFкB, diabetes

\section{Introduction}

Alloxan is widely used for the development of experimental diabetes to induce selective dysfunctioning of pancreatic $\beta$-cells (Rerup, 1970; Lenzen and Panten,
1988). The mechanism of alloxan-induced diabetes has been the subject of many investigations, and it is generally accepted that reactive oxygen species (ROS) are involved in the initiation of the damage that ultimately leads to $\beta$-cell death (Yamamoto et al., 1981; Uchigata et al., 1982; Oberley, 1988; Rho et al., 2000). However the cellular mechanism responsible for $\beta$-cell death is still unclear. Our previous studies showed that increase of cytosolic free calcium in pancreatic $\beta$-cells played an important role in the alloxan-induced ROS generation (Kim et al., 1991; Kim et al., 1994).

Evidences suggest that ROS act as signal molecules in the regulation of gene expression, cell proliferation, and cell death (Palmer and Paulson, 1997; Rhee, 1999). Moreover, ROS are now known to play a critical role in the up-regulation of gene expression involved in the inflammatory and autoimmune responses.

During the course of oxidative cell death, the redoxsensitive transcription factor NFKB is activated (Schreck et al., 1991; Behl et al., 1994; Schmidt et al., 1995; Du et al., 1999). NFKB is predominantly consisted of the two subunits of $\mathrm{p} 50$ and p65. These proteins are members of the NFKB/Rel family of transcription factors that are known to control various genes involved in the inflammatory mechanisms. Typically, NFкB is sequestered in the cytoplasm by the specific inhibitory protein I $\mathrm{kB}$. Activation and regulation of $\mathrm{NF} \kappa \mathrm{B}$ transition into the nucleus, where it can induce the transcription of NFKBdependent target genes, is tightly controlled by $1 \kappa B$ proteins (Baeuerle and Henkel, 1994; Baldwin, 1996).

Recently, Ho et al. $(1999,2000)$ suggested that inappropriate activation of NFKB by ROS might start a cascade of events that result in the inflammatory and autoimmune response in pancreas and inhibition of $N F \kappa B$ activation by antioxidants attenuated the severity of Type 1 diabetes. Once an autoimmune/inflammatory response is launched, the invading immune cells amplify ROS production, which ultimately destroys the $\beta$-cells. Thus, ROS are not simply cytotoxic agents that damage $\beta$-cells, but are key modulators of the cellular response pathways that initiate $\beta$-cell death and the development of Type 1 diabetes.

Diabetes mellitus is one of the most important health problems worldwide, showing high indices of prevalence and mortality. The inherent lack of antioxidant protection in the pancreatic islet may increase its sensitivity to diabetogenic agents that trigger ROS production (Lenzen et al., 1996; Tiedge et al., 1997). To date there have been different groups of hypoglycemic agents for clinical 
use, having characteristic profiles of side effects. Management of diabetes without any side effects is still a challenge to the medical communities.

A. xanthoides comes from the fruit of Amomum villosum Lour and it belongs to the family of Zingiberaceae. It has been used to promote the well-being state of physiological system including gastroenteric organs (Ou, 1989). In the present study, we investigated the preventive effect of $A$. xanthoides extract on alloxan-induced diabetes. Pretreatment with $A$. xanthoides extract inhibited alloxan-induced NFKB activation, dysfunctioning of $\beta$ cells, and consequencial hyperglycemia and hypoinsulinemia.

\section{Materials and Methods}

\section{Animals}

Specific pathogen-free female ICR mice were purchased from the Korean Research Institute of Chemistry Technology (Daejon, Korea) and were housed throughout the experiments in a laminar flow cabinet, and maintained on standard laboratory chow ad libitum. All mice were 10-12 weeks-old of age.

\section{Preparation of the extract}

For water extraction, $200 \mathrm{~g}$ of $A$. xanthoides was ground and extracted with boiling water for $4 \mathrm{~h}$. After the centrifugation at $3,000 \mathrm{~g}$ for $20 \mathrm{~min}$, the supernatant was concentrated under reduced pressure and freezedried.

\section{Effect of $\boldsymbol{A}$. xanthoides extract on alloxan-induced diabetes}

To induce diabetes, mice were injected with alloxan monohydrate via the tail vein in a dose of $60 \mathrm{mg} / \mathrm{kg}$. Alloxan monohydrate was dissolved in saline just before use. To examine the effect of $A$. xanthoides extract on the development of alloxan-induced diabetes, $A$. xanthoides extract $(2.5 \mathrm{mg} / \mathrm{kg}$ body weight) dissolved in saline was administered intraperitoneally 2 days before alloxan injection. Blood was obtained from the intra-orbital sinus. To minimize the effects of diurnal fluctuations, blood samples were collected at the same time every day.

\section{Determination of blood glucose and insulin}

Blood glucose was determined using glucose oxidase kit (Asan Pharm. Co., Korea), and serum insulin was assayed by standard radioimmunoassay technique (Amersham, USA).

\section{Electrophoretic mobility shift assay}

The nuclear extracts were prepared from the pancreases according to the method of Im et al. (1997). To inhibit endogenous protease activity, $1 \mathrm{mM}$ phenylmethylsulfonyl fluoride was added. Protein contents in nuclear extracts were measured using the Bradford method (Bradford, 1976). As a probe for the gel retardation

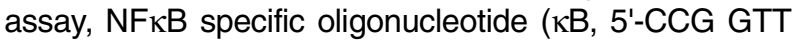
AAC AGA GGG GGC TTT CCG AG-3') was synthesized. The two complementary strands were annealed and labeled with $\left[\alpha-{ }^{32} \mathrm{P}\right] \mathrm{dCTP}$. Labeled oligonucleotides (10,000 cpm), $10 \mu \mathrm{g}$ of nuclear extracts, and binding buffer (10 mM Tris- $\mathrm{HCl}, 500 \mathrm{mM} \mathrm{KCl}, 10 \mathrm{mM}$ EDTA, $50 \%$ glycerol, $100 \mathrm{ng}$ of poly(dl.dC), and $1 \mathrm{mM} \mathrm{DTT,} \mathrm{pH}$ 7.6) were incubated for $30 \mathrm{~min}$ at room temperature in a final volume of $20 \mu \mathrm{l}$. The reaction mixture was analyzed by electrophoresis on a $4 \%$ polyacrylamide gel in $0.5 \mathrm{X}$ Tris-borate buffer. Specific binding was confirmed by competition with a 50-fold excess of cold $\mathrm{\kappa B}$ oligonucleotide.

\section{Histological examination}

Following ablation 3 days after alloxan administration, pancreatic tissue was collected and the islet area was examined. The pancreas was fixed in $10 \%$ formalin, embedded in paraffin, and stained with hematoxylin and eosin. At least 5 sections from each specimen, obtained at varying depths, were examined by light microscopy (Kim et al., 1991).

\section{Statistical analysis}

Statistical analysis of the data was performed with an unpaired Students $t$-test. Differences with $P<0.05$ were considered statistically different.

\section{Results and Discussion}

Diabetes is possibly the world's fastest growing metabolic disease, so does the need for more appropriate therapies grow. Management of diabetes without any side effects is still a challenge to the medical community. Use of traditional plant medicines has been in practice for centuries at different regions of the world more so than others in order to alleviate diabetic symptoms. Despite insufficient evidences to support its therapeutic efficacy, the use of herbal medicine has increased considerably. A typical pharmacological action of $A$. xanthoides is considered to be a protective effect of gastrointestinal tract. Here we report another effect of $A$. xanthoides against alloxan-induced development of diabetics.

Mice that received $60 \mathrm{mg} / \mathrm{kg}$ of alloxan became hyperglycemic at $72 \mathrm{~h}$ (Figure 1A). Their blood glucose levels at $72 \mathrm{~h}$ were greater than $500 \mathrm{mg} / \mathrm{dL}$, a value well within the acceptable diabetic range. In contrast, the mice pretreated with $A$. xanthoides extract $(2.5 \mathrm{mg} / \mathrm{kg}$, ip) and treated with alloxan remained to maintain blood glucose values in the normal range. This glucose lowering effect 

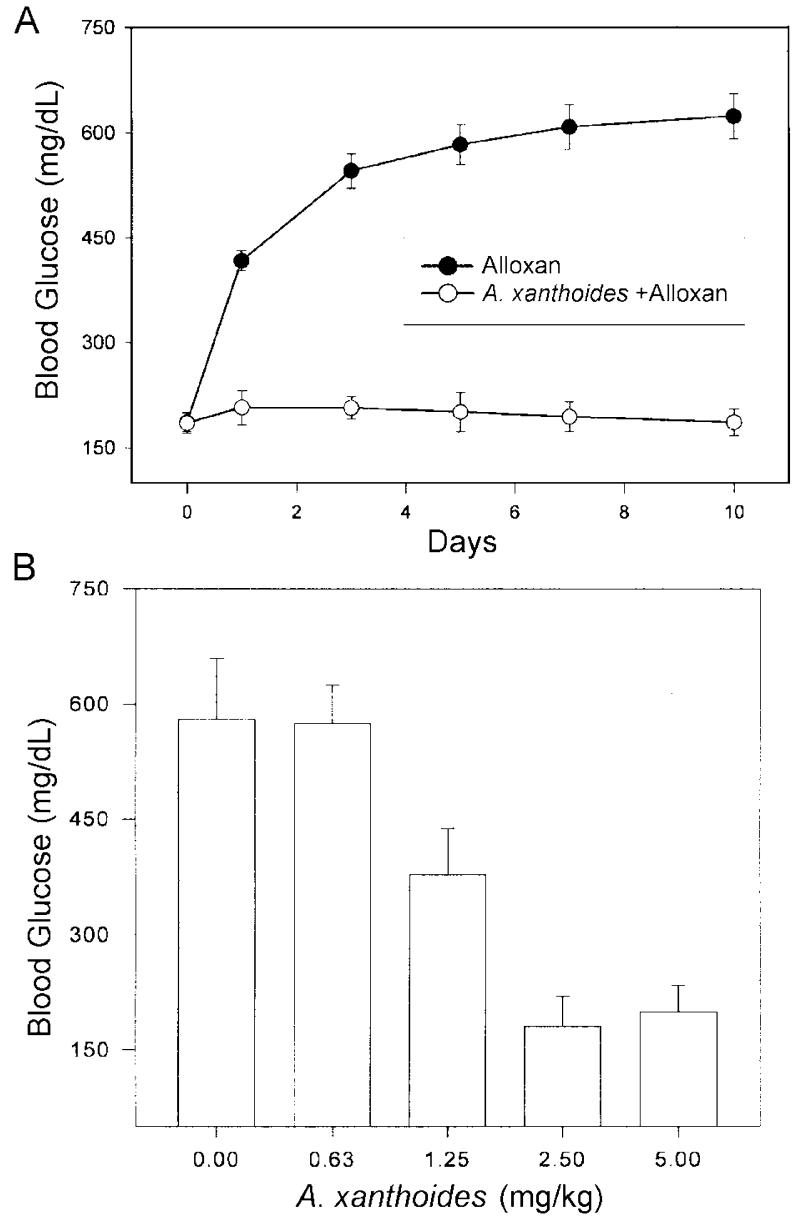

Figure 1. Effect of pretreated $A$. xanthoides extract on blood glucose levels in alloxan-treated mice. Alloxan $(60 \mathrm{mg} / \mathrm{kg})$ was injected via the tail vein of mice with or without pretreatment of $A$. xanthoides extract given intraperitoneally twice a day for 2 days prior to alloxan injection. The doses of pretreated $A$. xanthoides extract were either $2.5 \mathrm{mg} / \mathrm{kg}(\mathrm{A})$ or various ranges (B). Blood glucose was measured as described in "Materials and Methods". Each value denotes the mean \pm S.D. of six separate experiments.

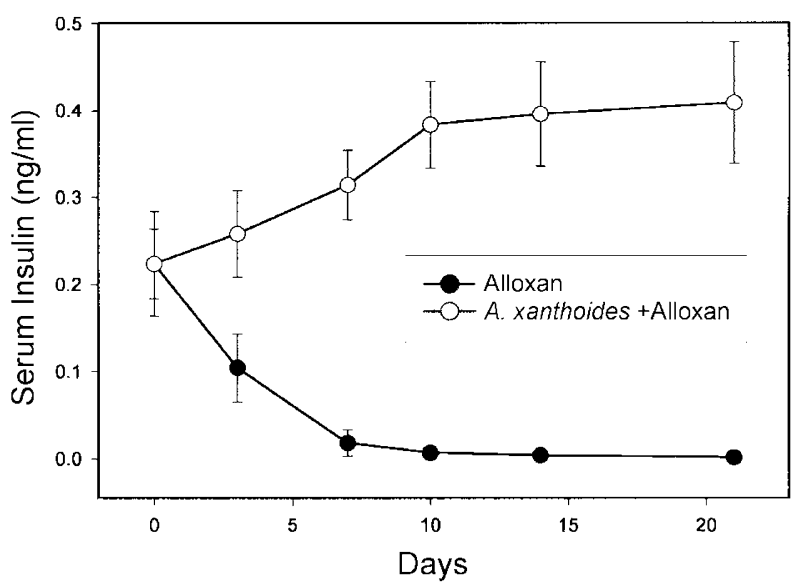

Figure 2. Effect of pretreated $A$. xanthoides extract on blood insulin levels in alloxan-treated mice. A. xanthoides extract $(2.5 \mathrm{mg} / \mathrm{kg})$ was given intraperitoneally twice a day for 2 days before alloxan injection. Blood insulin levels were determined by radioimmunoassay. Each value denotes the mean \pm S.D. of six separate experiments. was dose-dependent (Figure 1B). A. xanthoides extract treatment alone (no alloxan) did not affect blood glucose values in the mice (data not shown). Animals injected with alloxan alone showed a significant decrease in blood insulin levels in comparison with those of controls. Pretreatment of mice with $A$. xanthoides extract $(2.5 \mathrm{mg} /$ $\mathrm{kg}$ ) attenuated the severity of alloxan-induced hypoinsulinemia (Figure 2). Thus, $A$. xanthoides extract at this dose are considered to be protective against the dose used to elicit alloxan-induced diabetes.

To elucidate the cellular effect of $A$. xanthoides extract, a histological examination on pancreatic islets was

(A)

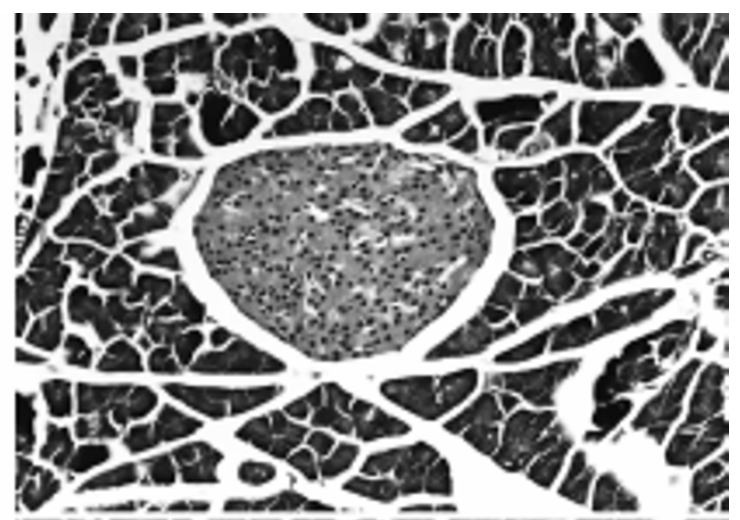

(B)

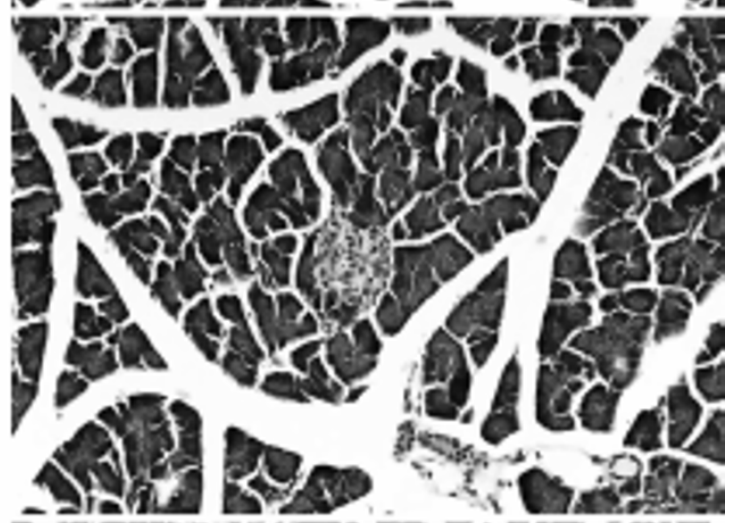

(C)

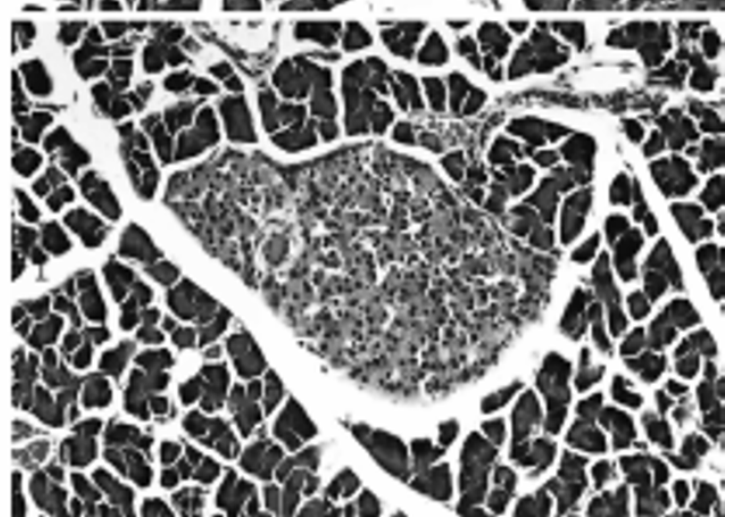

Figure 3. Histologic examination of pancreas. Pancreases were obtained 3 days after from normal control mouse (A), alloxan-induced diabetic mouse (B), and $A$. xanthoides extract (2.5 mg/kg)-pretreated mouse before alloxaninjection (C). The specimens were stained with hematoxylin and eosin and examined by light microscopy $(\times 200)$. 


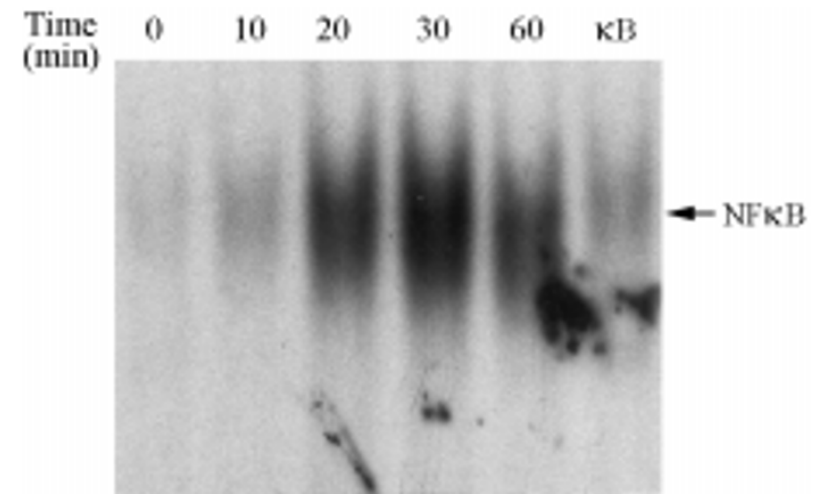

Figure 4. Time course of $\mathrm{NFKB}$ activation in the pancreas of mice injected with alloxan. Mice were injected with $60 \mathrm{mg} / \mathrm{kg}$ of alloxan or saline control. Mice were sacrificed at the indicated time, and pancreatic tissues were removed and immediately frozen. Nuclear extracts were incubated with ${ }^{32} \mathrm{P}$ labeled $\kappa B$ oligonucleotide and electrophoresed on a $4 \%$ polyacrylamide gel. A 50 -fold excess of unlabelled $\kappa B$ oligonucleotide was added to nuclear extract of $30 \mathrm{~min}$ as a competitor to confirm the specificity of NFKB binding. This experiment was repeated three times with similar results.

performed 3 days after alloxan administration with or without $A$. xanthoides extract pretreatment. Alloxan-treated mouse showed a marked change of pancreatic islets (Figure 3B): the islet decreased in its size and contained relatively small numbers of cells whereas numerous well-defined cells were seen in the pancreatic islets of the normal and $A$. xanthoides extract-pretreated mice (Figure $3 \mathrm{~B}$ and $\mathrm{C}$ ).

To elucidate the protective mechanism against alloxaninduced diabetes, we next examined the ability of alloxan to induce the activation of $\mathrm{NF} \kappa \mathrm{B}$ and determined if $A$. xanthoides extract could inhibit NFKB activation. Figure 4 shows a representative EMSA radiograph that depicts the ${ }^{32} \mathrm{P}$-DNA/NFKB complex present in the nuclear extracts of the pancreas after injection of alloxan at various time points. The specificity of $\mathrm{NF} \kappa \mathrm{B}$ binding was confirmed by using an excess of unlabeled oligonucleotides, which comprise of $N F \kappa B$ binding sites as a specific competitor. NFKB activation was maximal at 30 min after alloxan injection in pancreatic nuclear extracts and still sustained until $60 \mathrm{~min}$. Figure 5 illustrates that the pretreatment with $A$. xanthoides extract inhibits alloxan-induced NFKB activation. Similar to Figure 4, $\mathrm{NF} \kappa \mathrm{B}$ activation was observed at $30 \mathrm{~min}$ after alloxan administration. However, pretreatment of $A$. xanthoides extract ( 2 day before alloxan administration) prevented any activation of $\mathrm{NF} \kappa \mathrm{B}$.

There is no doubt that alloxan induces NFкB activation in vivo and this is well correlated with the works of Ho et al. $(1999,2000)$. It is interesting to note that alloxan rapidly induces NFKB activation in pancreas within 30 min after an intravenous injection of alloxan. Pretreatment with $A$. xanthoides extract alone did not induced $\mathrm{NF} \kappa \mathrm{B}$ activation in the pancreas.

In conclusion, there appears to be a good correlation

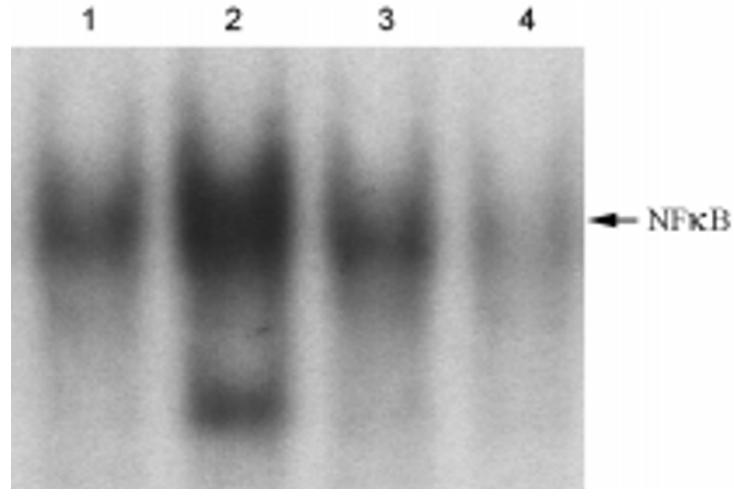

Figure 5. Inhibition of NFKB activation in pancreas by pretreatment of $A$. xanthoides extract. Mice were treated with alloxan in the presence or absence of $A$. xanthoides extract and NFKB activation was determined by electrophoretic mobility shift assay. Lane 1, control mouse; Lane 2, alloxantreated mouse (for $30 \mathrm{~min}$ ); Lane 3 , Pretreatment with $A$. xanthoides extract before alloxan injection; Lane 4, A 50-fold excess of unlabelled $\kappa B$ oligonucleotide was added to nuclear extract of alloxan treated mouse. This experiment was repeated three times with similar results.

between the protective effect of $A$. xanthioides against alloxan-induced diabetics and its preventing effect of

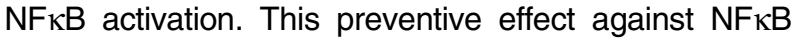
activation may explain the antidiabetic effect of $A$. xanthoides extract.

\section{Acknowledgements}

We thank to C.H. Song (Department of Anatomy, Chonbuk National University Medical School) for the histologic examination.

\section{References}

Baeuerle PA, Henkel T. Function and activation of NF- $\mathrm{KB}$ in the immune system. Annu Rev Immunol 1994;12:141-79

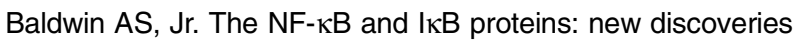
and insights. Annu Rev Immunol 1996;14:649-83

Behl C, Davis JB, Lesley R, Schubert D. Hydrogen peroxide mediates amyloid beta protein toxicity. Cell 1994;77:817-27

Bradford MM. A rapid and sensitive method for the quantitation of microgram quantities of protein utilizing the principle of protein-dye binding. Anal Biochem 1976;72:248-54

Du X, Stocklauser-Farber K, Rosen P. Generation of reactive oxygen intermediates, activation of $\mathrm{NF}-\mathrm{\kappa B}$, and induction of apoptosis in human endothelial cells by glucose: role of nitric oxide synthase? Free Radic Biol Med 1999;27:752-63

Ho E, Chen G, Bray TM. Supplementation of $N$-acetylcysteine inhibits NFKB activation and protects against alloxan-induced diabetes in CD-1 mice. Faseb J 1999;13:1845-54

Ho E, Chen G, Bray, TM. Alpha-phenyl-tert-butylnitrone (PBN) inhibits NFKB activation offering protection against chemically 
induced diabetes. Free Radic Biol Med 2000;28:604-14

Im SY, Han SJ, Ko HM, Choi JH, Chun SB, Lee DG, Ha TY, Lee HK. Involvement of nuclear factor- $\kappa B$ in platelet-activating factor-mediated tumor necrosis factor- $\alpha$ expression. Eur $\mathrm{J}$ Immunol 1997;27:2800-4

Kim HR, Rho HW, Park JW, Kim JS, Kim UH, Jhee EC. Protection of alloxan-induced $\beta$-cell damage of rat pancreas by $\mathrm{Ca}^{2+}$-antagonists. Kor J Biochem 1991;23:141-46

Kim HR, Rho HW, Park BH, Park JW, Kim JS, Kim UH, Chung MY. Role of $\mathrm{Ca}^{2+}$ in alloxan-induced pancreatic beta-cell damage. Biochim Biophys Acta 1994;1227:87-91

Lenzen S, Panten U. Alloxan: history and mechanism of action. Diabetologia 1988;31:337-42

Lenzen, S, Drinkgern J, Tiedge M. Low antioxidant enzyme gene expression in pancreatic islets compared with various other mouse tissues. Free Radic Biol Med 1996;20:463-66

Oberley LW. Free radicals and diabetes. Free Radic Biol Med 1988;5:113-24

Ou M. Chinese-English manual of common-used in traditional Chinese medicine. 1989, pp. 368-69, Joint Publishing Co., Ltd., Hong-Kong

Palmer HJ, Paulson KE. Reactive oxygen species and antioxidants in signal transduction and gene expression. Nutr Rev 1997:55:353-61

Rerup CC. Drugs producing diabetes through damage of the insulin secreting cells. Pharmacol Rev 1970;22:485-18

Rhee SG. Redox signaling: hydrogen peroxide as intracellular messenger. Exp Mol Med 1999;31:53-59

Rho HW, Lee JN, Kim HR, Park BH, Park JW. Protective mechanism of glucose against alloxan-induced $\beta$-cell damage: Pivotal role of ATP. Exp Mol Med 2000;32:12-17

Schmidt KN, Amstad P, Cerutti P, Baeuerle PA. The roles of hydrogen peroxide and superoxide as messengers in the activation of transcription factor NF-кB. Chem Biol 1995;2:1322

Schreck R, Rieber P, Baeuerle PA. Reactive oxygen intermediates as apparently widely used messengers in the activation of the NF- $\mathrm{KB}$ transcription factor and HIV-1. EMBO J 1991;10:2247-58

Tiedge M, Lortz S, Drinkgern J, Lenzen S. Relation between antioxidant enzyme gene expression and antioxidative defense status of insulin-producing cells. Diabtetes 1997;46:1733-42

Uchigata $Y$, Yamamoto H, Kawamura A, Okamoto H. Protection by superoxide dismutase, catalase, and poly(ADP-ribose) synthetase inhibitors against alloxan- and streptozotocininduced islet DNA strand breaks and against the inhibition of proinsulin synthesis. J Biol Chem 1982;257:6084-88

Yamamoto $\mathrm{H}$, Uchigata $\mathrm{Y}$, Okamoto $\mathrm{H}$. Streptozotocin and alloxan induce DNA strand breaks and poly(ADP-ribose) synthetase in pancreatic islets. Nature 1981;294:284-86 